UDC 711.4 .01

https://doi.org/10.51488/1680-080X/2021.4-04

IRSTI 67.25.03, 67.25.19

\author{
A.K. Tuyakayeva ${ }^{1}$, K.D. Kerimova ${ }^{1 *}$ \\ ${ }^{1}$ International Educational Corporation (KazGASA campus), Almaty, Kazakhstan
}

Information about the authors:

Tuyakayeva Ainagul Kayrbaevna - Associate Professor of the Architecture Department, International Educational Corporation (KazGASA campus), Almaty, Kazakhstan

https://orcid.org/0000-0002-6470-7975, e-mail: a.tuyakayeva@kazgasa.kz

Kerimova Kamilya Dolkunovna - Master's student of the Architecture Department, International Educational Corporation (KazGASA campus), Almaty, Kazakhstan

https://orcid.org/0000-0003-4249-0573, e-mail: kami_kd@mail.ru

\title{
PRE-PROJECT ANALYSIS OF WATERBANK AREAS
}

Annotation. This article examines the experience of pre-design analysis for the architectural and planning organization of the coastal areas of the cities of Kazakhstan in order to identify the problems and the most effective methods for eliminating them and improving the quality of the environment. The results of a sociological survey of the population and a field survey are presented.

Keywords: pre-design analysis, coastal areas, sociological research, modernization of water spaces, city embankments, reorganization of coastal zones, water area.

\section{Introduction}

Coastal territories in cities often determine the main compositional axis, act as a recreational source, allow improving the ecological situation, and improve the quality of urban life. Numerous studies have shown that embankments are the favorite and most visited places of citizens. Proper organization of urban spaces has a great impact on the social, economic and even political sphere. On this basis, it is very important to pay sufficient attention to the development and modernization of coastal and water spaces, as it leads to a competitive advantage between cities in the struggle for a clean environment and a comfortable standard of living [1].

\section{Material and methods}

The work used methods of pre-project analysis of the city's waterfront areas: "social design" (sociological research), field survey, comparative assessment, photofixation, which form the basis of the developed in the future approaches to the architectural and planning organization.

\section{Results and discussion}

In the course of research work to develop principles of architectural and planning organization of the embankments in the cities of Kazakhstan, the pre-project analysis of the coastal areas was carried out. On the basis of a field survey, the current state of the embankments of large cities in Kazakhstan was analyzed; as a result, a data table of 17 cities was formed, where types of water bodies, their names, as well as the state and problems, reflected in the photo-fixation were specified [2]. 
In the course of the study, the historical background and features of the development of embankments and their functions in cities were studied, as well as the features of the formation of coastal spaces in a number of large cities of Kazakhstan, including the largest - Almaty and Shymkent [3].

During the study were also studied and engineering solutions for the proper improvement of embankments, where it is proposed to apply slopes, gabion structures and retaining walls, etc., to prevent erosion of the banks [4].

To develop subsequent design proposals for the organization of the embankment environment, the regulatory and legal framework of coastal areas has been studied, all restrictions within the boundaries of water protection zones and embankment strips have been analyzed [4].

The research revealed the main problems of architectural and planning organization of embankments:

- lack of a systematic, comprehensive approach to the organization of recreational areas in the structure of coastal areas;

- violation of the norms of water protection legislation;

- pollution of coastal territories;

- chaotic development of the nearby territories;

- insufficient improvement of the territory;

- lack of attractive objects and public spaces for the urban population on the coastal areas, etc. (Fig. 1) [4].

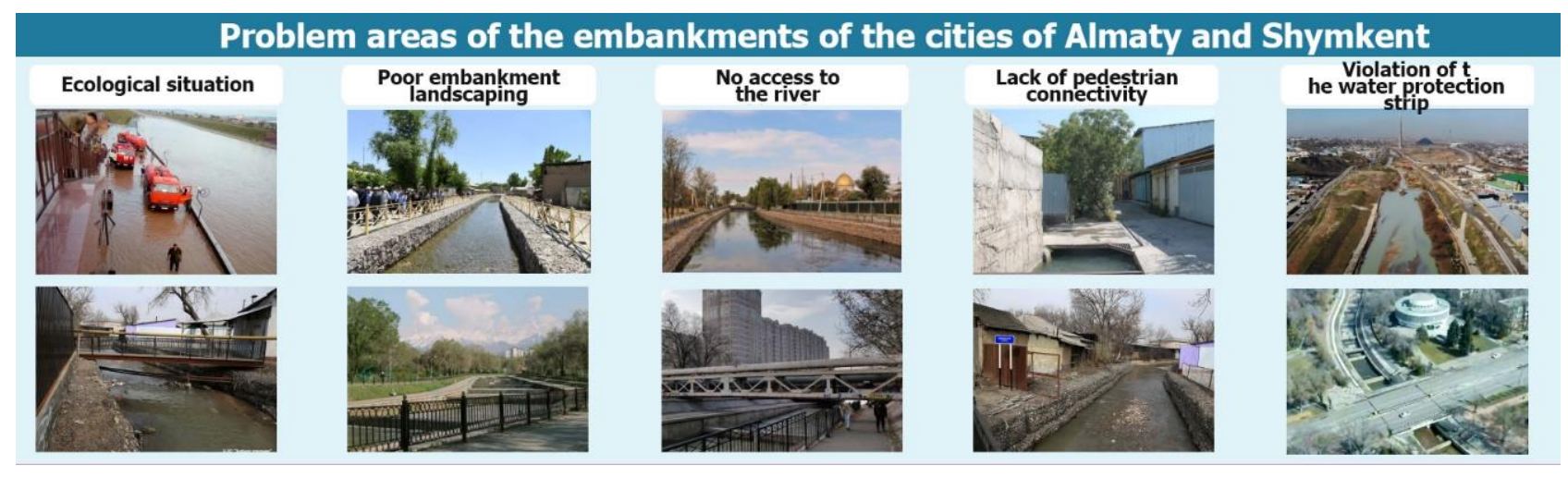

Figure 1 - Problem areas of the embankments of Almaty and Shymkent city

[Author's material]

In order to improve the overall condition of the embankments in the cities of Almaty and Shymkent, it is necessary to increase the importance of these areas in the life of the population, and for their further reconstruction - to consider the opinion of the citizens, the end users of this transformation. For this purpose, an experimental social research was conducted in the process of study. The opinion of the citizens on the general state of the embankments in the city was revealed, the most attractive areas were identified and their preferences regarding their further reconstruction were determined. The total number of respondents was 200 people in Almaty, 100 respondents in Shymkent. The age of respondents ranged from 15 to 65 years (Fig. 2-3). 
Results of the survey of Almaty city showed that $64.5 \%$ of the respondents are not satisfied with the current condition of the embankments. Meanwhile, demand for recreation by the water (river embankments, bodies of water) is preferred by $39.7 \%$ of respondents; $33.3 \%$ visit embankments once a month; $64.5 \%$ visit embankments only in warm seasons (summer/autumn/spring). In terms of the popularity of visits in Almaty prefer the embankments of the rivers Esentai, Bolshaya Almatinka and Terrenkur. According to the respondents, the Sairan lake embankment, the Malaya Almatinka river embankment and the Big Almatinka river embankment, as well as the BAC embankment need reconstruction more than others.



Your age: *

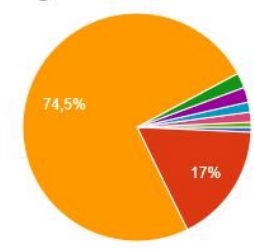

How long have you lived in Almaty? *



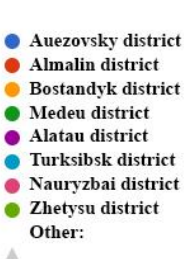

- under 15

under 15

under 35

under 45 years old

under 55 years old

under 65

over 65

other

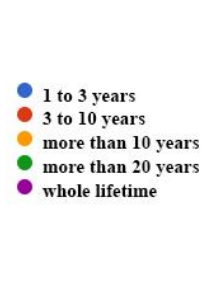

How often do you visit waterfronts?
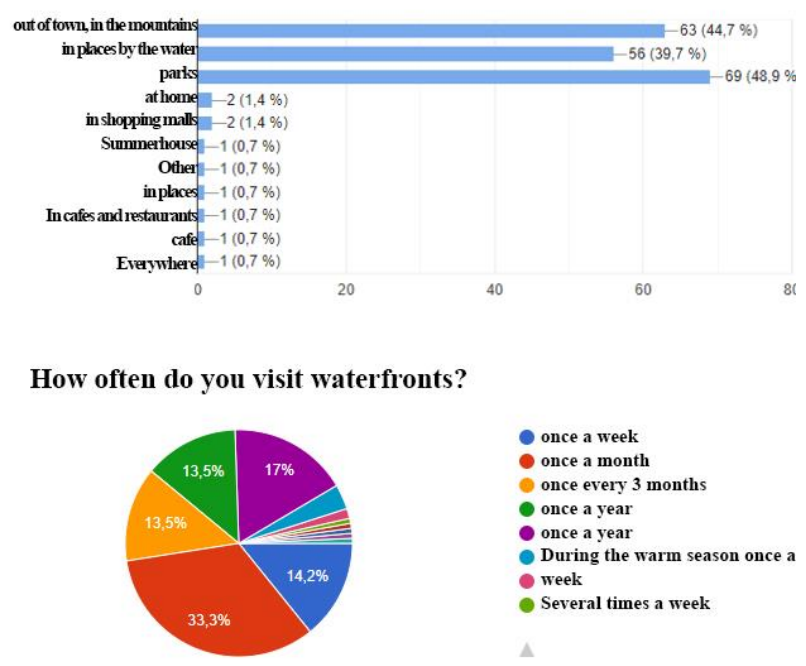

$$
\begin{aligned}
& \text { once a week } \\
& \text { once a month } \\
& \text { once every } 3 \text { months } \\
& \text { once a year } \\
& \text { once a year } \\
& \text { During the warm season once a } \\
& \text { week } \\
& \text { Several times a week }
\end{aligned}
$$

What time of year do you visit waterfronts?

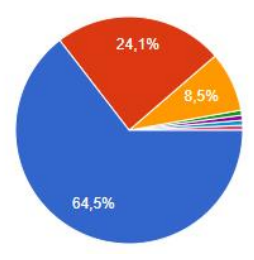

- in the warm season (summer/fall/spring
spring) warm and cold season only in summer I do not visit Other - Various

Figure 2 - Results of a sociological survey on the embankments of Almaty [Author's material]

Processing the responses of the social survey on the city of Almaty revealed the respondents' suggestions for improving embankments and their needs: to improve the improvement of embankments - more alleys, benches, lights, more viewing, sports, playgrounds and open spaces (amphitheater, stage), increase the number of small architectural forms, art objects; increase the area of landscaped parks/squares; solve the problem of the adverse sanitary condition of embankments; increase the number of cultural and leisure facilities near embankments.

Social research in the city of Shymkent showed that $68.1 \%$ of respondents are not satisfied with the current state of the embankments. At the same time, $31.1 \%$ of respondents prefer recreation in places near water; $32.4 \%$ of questioned in Shymkent city visit quays once a month; $62.2 \%$ visit quays only in warm seasons (summer/autumn/spring). 
In Shymkent city, the most popular embankments among the respondents were: the embankment of the river Koshkarat and the embankment of the lake Tulpar. The survey showed that in Shymkent city, the Karasu river embankment and the embankment of the Badam river need reconstruction more than others.

The analysis of the data obtained as a result of the social survey allowed to determine the problem areas for further reconstruction of the embankments in Shymkent city: the lack of landscaped areas of parks and squares; not good enough improvement of the embankments; no pedestrian access to the river; unfavorable sanitary condition of the embankments, insufficient number of viewing, sports and playgrounds, open spaces on the embankments; lack of cultural and leisure facilities near embankments (cafes/restaurants/terrace); lack of architectural forms In the course of the social survey, the personal wishes of the residents to improve the condition of the embankments were also processed. The study of the functional areas of the coastal territories of the cities, the identification of common problems of the architectural and planning organization of the embankments directed the research question to a more detailed study at the local level.

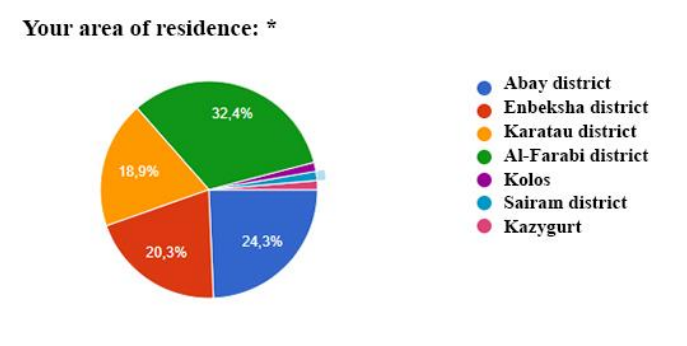

Your age: *

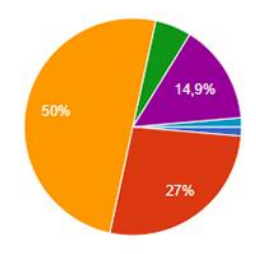

How long have you lived in Shymkent? *
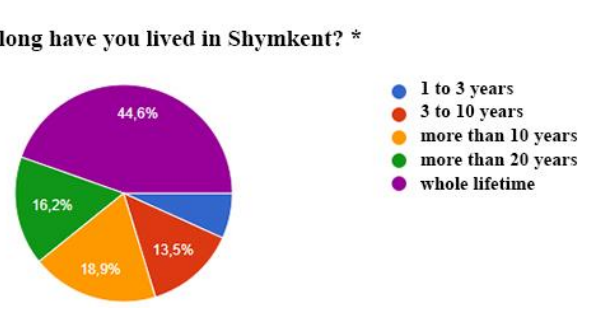

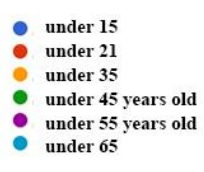

How often do you visit waterfronts?

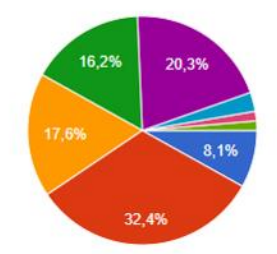

What time of year do you visit waterfronts?



- Never

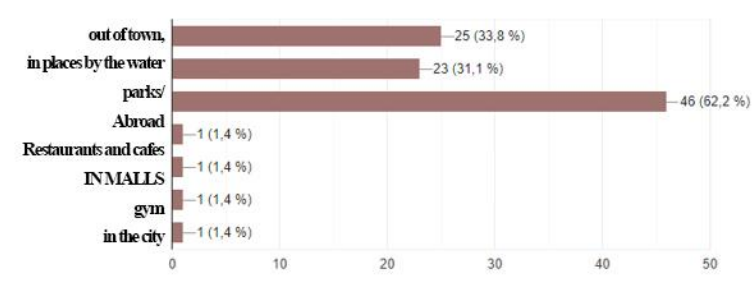

once a week

once a month

once a year

once a year

- Various

- Didn't know we had a prom-

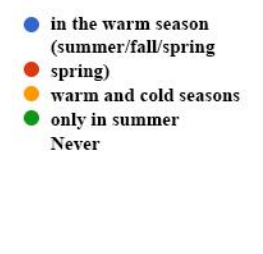

Figure 3 - The results of the sociological survey on the embankments of Shymkent city [Author's material]

\section{Conclusions}

1. The sociological survey presented in the pre-project analysis was the basis of further research for the development of project proposals. It demonstrated the value of embankment territories for the urban population, showed the interest of citizens to the issue under study. Urban residents are not indifferent to the quality of urban life; they took the problem under consideration responsibly enough. 
2. The introduction of "social designing" elements into practice allows increasing the degree of projects' accordance with the needs of the population, will provide the coordination of interests of different consumers of the project documentation; at the same time, the selection of optimality criteria in the comparative estimation of variants and so on is provided.

3. Prospect of the development of rivers and coastal territories of cities assumes the formation of new approaches to the design of embankments, which remain the element of a natural skeleton of a city and its city-forming new city landscapes with the maintenance of comfortable conditions and access of inhabitants to the river.

4. Proper organization of functional zones of coastal territories will allow increasing their importance in the city and will have a favorable influence on the social and economic sphere. Therefore it is essential to pay attention to the revitalization of city embankments, returning these territories to inhabitants, increasing their design level. In this, an important role is given to improving the methods of pre-project analysis.

\title{
References:
}

1. Jared Green (2015) Designed for the Future: 80 Practical Ideas for a Sustainable World. ISBN: 1616893001, ISBN: 978-1616893002

2. Tuyakayeva A.K., Kerimova K.D. Sovremennoe sostoyanie arhitekturno-planirovochnoi organizacii naberezhnyh krupnyh gorodov Kazakhstana [The current state of the architectural and planning organization of the embankments of large cities of Kazakhstan]. Sbornik XVI Mezhdunarodnoi nauchno-practicheskoi konferentsi=Collection of the XVI International Scientific and Practical Conference. V. Tatlin: 2020, 105-115. (in Russ.)

3. Tuyakayeva A.K., Kerimova K.D. Osobennosti arhitekturno-planirovochnoy organizacii pribrezhnyh territoriy gorodov Uzhnogo Kazakhstana [Features of the architectural and planning organization of the coastal territories of the cities of South Kazakhstan]. Sbornik XVI Mezhdunarodnoi nauchno-practicheskoi konferentsi=Collection of the XVI International Scientific and Practical Conference. V. Tatlin: 2020, 165-172. (in Russ.)

4. Tuyakayeva AK, Kerimova KD (2021) Bulletin of Kazakh Leading Architecture Building Academy 3: P.60-71. (in Russ.) DOI: https://doi.org/10.51488/1680-080X/2021.3-08

\author{
А.К.Туякаева ${ }^{1}$ К.Д. Керимова ${ }^{1^{*}}$ \\ ${ }^{1}$ Халықаралық білім беру корпорациясы (ҚазБСҚА кампусы), Алматы, Қазақстан
}

\begin{abstract}
Авторлар туралы мәліметтер:
Туякаева Айнагүл Қайырбайқызы - сәулет кандидаты, қауымдастырылған профессор, Халықаралық білім беру корпорациясы (ҚазБСҚА кампусы), Алматы, Қазақстан https://orcid.org/0000-0002-6470-7975, e-mail: a.tuyakayeva@kazgasa.kz

Керимова Камиля Долкуновна - магистрант, Халықаралық білім беру корпорациясы (ҚазБСҚА кампусы), Алматы, Қазақстан

https://orcid.org/0000-0003-4249-0573, e-mail: kami_kd@mail.ru
\end{abstract}




\title{
ЖАҒАЛАУ АЙМАҚТАРДЫН ЖОБАЛЫҚ ТАЛДАУЫ
}

Андатпа. Бұл мақ̧алада Қазақ̧стан қ̧алаларының қ̧оршаван орта сапасын жақ̧сартудың жолында невұрлым тиімді ддістерін белгілеп, мәселелерін анықтап жою мақссатында, жавалау манындавы аумақтарын сәулеттік жобалау алдындавы талдау тәжірибесі құарастырылады. Халық арасында жүргізілген әлеуметтік сауалнама мен аумақты зерттеу нәтижелері келтірілген.

Түйін сөздер: жобалау алдындавы талдау, жавалау аймақтары, сочиологиялыққ зерттеулер, су кеністігін жаңуzырту, қала жавалаулары, жавалау аймақттары, акваторияны қ̧айта құру.

\author{
А.К.Туякаева ${ }^{1}$, К.Д. Керимова ${ }^{1^{*}}$ \\ ${ }^{1}$ Международная образовательная корпорация (кампус КазГАСА), \\ Алматы, Казахстан
}

\section{Информация об авторах:}

Туякаева Айнагуль Кайырбаевна - кандидат архитектуры, ассоциированный профессор, Международная образовательная корпорация (кампус КазГАСА), Алматы, Казахстан https://orcid.org/0000-0002-6470-7975, e-mail: a.tuyakayeva@kazgasa.kz

Керимова Камиля Долкуновна - магистрант, Международная образовательная корпорация (кампус КазГАСА), Алматы, Казахстан

https://orcid.org/0000-0003-4249-0573, e-mail: kami_kd@mail.ru

\section{ПРЕДПРОЕКТНЫЙ АНАЛИЗ НАБЕРЕЖНЫХ ТЕРРИТОРИЙ}

\footnotetext{
Аннотация. В данной статье рассматривается опыт предпроектного анализа для архитектурно-планировочной организачии прибрежных территорий городов Казахстана с целью определить проблемы и обозначить наиболее эффективные методы их устранения и совершенствования качества среды. Приведены результаты сочиологического опроса населения и натурного обследования.

Ключевые слова: предпроектный анализ, прибрежные территории, сочиологические исследования модернизаиия водных пространств, городские набережные, реорганизаичия береговых зон, акватория.
} 